\title{
Efficacy of Nifty Index Options through BSM Model
}

\author{
K. Prabhakar Rajkumar, D. Subalakshmi
}

\begin{abstract}
Options are one of the products in financial derivatives, which gives the rights to buy and sell the product to an option holder in pre-fixed price which known as the strike price or exercise price at certain periods. Options contract was existed in various countries for long time, but it became very popular among the investors when the Fisher Black, Myron Scholes and Robert Merton were introduced the Black-Scholes Model in the year of 1973. This model was formerly developed by these three economists who were also receiving the Nobel prize for finding this innovative model. This model is mainly used to deal with the theoretical pricing challenge in options price determination. In India the trading in Index Options commenced on 4th June 2001 and Options on individual securities commenced on 2nd July 2001. There are many types in options contracts like stock options; Index options, weather options, real options and etc. This study has mainly been focusing on Nifty 50 index options which are effectively trade at NSE. This paper goes to describe about the importance of options pricing and how the BSM model has effectively used to find the optimum price of the theoretical value of call and put options.
\end{abstract}

Key Words: Index Options, BSM Model, Market Price, Options Pricing Model.

\section{INTRODUCTION}

Option Pricing Models are providing a fair market value for an option. With this fair value the investors who all are involved in options contract can obtain a maximum profit by use this value as a tool for their trading strategies. This option, pricing model was mainly used by finance professionals to reduce their risk against the loss in the way of options payoff ${ }^{1}$. There are many standard models were available for option pricing like Binomial Tree Model, Black Scholes Merton Model, Jump Diffusion Model and many others were prevailing in the capital market for the perfect replaceable of option pay off using the underlying assets ${ }^{2}$. But this may be possible in the way of theory aspect, but however, in real way, the replica of the option's payoff may not be real. It may not correctly hedge the risk which is associated with the call what we have just written. Among these models, BSM model was used widely for deriving a fair option value for the product in the stock market. Here we analyze deeply how this model were differ from other option pricing models and how this model were effectively used in the period from 2011 to 2015 which we are taking as our research period.

Revised Manuscript Received on July 22, 2019.

Dr. K. Prabhakar Rajkumar, Assoc Prof, Dept of Commerce, Periyar University, Salem - 11, Tamil Nadu, India.

D. Subalakshmi, Ph.D Scholar, Dept of Commerce, Periyar University, Salem - 11, Tamil Nadu, India.

Email : kudalkprk6@yahoo.co.in

\section{Black Scholes Model (1973)}

The BSM model was first introduced in the year of 1973 and its effect on determination of option pricing is an evolution in stock market history. With this BSM model we derive the differential equation for both call and put option. After this model was found by Fisher Black and Myron Scholes the notations were apply as stock price for $\mathrm{S}, \mathrm{K}$ is the exercise price, $r$ is the risk free interest rate, $t$ is meant for time-to-maturity and $\sigma$ is the volatility, c denote European call price and $\mathrm{p}$ is European put price and $\mathrm{N}(\mathrm{x})$ is the standard cumulative normal-distribution. These notations are also known as a factor which affecting this model. Here except the factor of volatility rest all were known before itself and this volatility factor alone is estimated one in the way of measuring the implied volatility for a future period.

The assumptions of Black Scholes Model ${ }^{3 \& 10}$ were following

- $\quad$ No dividend in stock.

- It deals with only European options.

- $\quad$ There is no any transaction cost and information are available at free of cost.

- $\quad$ The short term interest rate is constant.

- $\quad$ There is no arbitrage, riskless profit, opportunity

- It is possible to borrow and lend any amount of money at the riskless rate and the probability distribution of return also normal.

- $\quad$ There is a possible way to buy or sell any amount of stock at free flow time.

The theoretical value of Black-Scholes options prices are not a prominent value what we could see in the options market. But in any case if this model was correct, then the options with the same expiration date for the same stock would have the same implied volatility which is not to be encountered on the market. However, the traders, investors and who all are involved in the options market were using the implied volatility to calculate the price of options. The perceived relation between the implied (Black and Scholes, 1973) volatility and the strike price for a given maturity were called as volatility smile. In the same way the relation between the implied volatility and maturity for a given strike is called as structure of volatility ${ }^{2}$. 


\section{Options and Risk Management}

The Black-Scholes Model were perfectly described about the lognormal distribution of the price dynamics in the options market. The transaction costs and volatility of underlying cost were not constant as it mentioned in the assumptions of BSM model. If this model was correct, then the options markets may not be exist, and each option would have only one real price. But in real practice, the traders in options were identified different source of risk factors that change the value of the call and put: where, the stock price $(\mathrm{S})$, strike price $(\mathrm{K})$, time $(\mathrm{t})$, volatility $(\sigma)$ and the interest rate (r). Then, they form an estimated replicating assortment for the written call option. The value of this portfolio has to change by the same amount as like that option (at least for small changes in the factors) ${ }^{4}$.

\section{Aim of the study}

1. To analyze the efficacy of Nifty index options through

Black-Scholes Options pricing model.

\section{REVIEW OF LITERATURE}

Debatia Mohanti (2013) has examined efficacy of the Indian options market by ex-ante test of the lower boundary conditions by comparison of ex-post test results which tested with respect to liquidity, maturity and moneyness ${ }^{5}$. In his another study, he presents his result as the evidence on the market efficiency of the S\&P CNX Nifty index options traded on the NSE of India, by using the BSM model for determine the dynamic hedging strategy?.

Lucy F. Ackert, Yisong S. Tian (2001) investigated in his study that whether the index options are priced accurately relatively to other theoretical pricing relationships which implied by no arbitrage conditions before and after the inception of SPDRs trading ${ }^{6}$. There are many methods are there to find the efficiency of index options based on arbitrage arguments which included many tests based on box spread, lower boundary conditions and put call parity.

Joshua Krausz (1985) analyzed in his study about the informational content of the Black-Scholes (BS) option pricing model using the Newton-Raphson (NR) numerical analysis technique to solve simultaneous pairs of options for their implied parameter values and employs these results in market efficiency hedging tests ${ }^{7}$.

Alok Dixit et al (2010) assess the informational efficiency of S\&P CNX Nifty index options in the Indian Securities Market. In this paper the informational efficiency of implied volatilities (IVs) has been tested vis-a-vis select conditional volatility models, namely, $\operatorname{GARCH}(1,1)$ and EGARCH $(1$, 1). The tests have been carried out for "in-the-sample" as well as "out-of-the-sample" forecast efficiency of implied volatilities ${ }^{8}$.

\section{RESEARCH METHODOLOGY}

In this study we used both primary data for theoretical and secondary data for calculation purpose from various official sites. The secondary data which contains the daily closing price, strike price of S\&P CNX Nifty 50 Index Options contracts from January 1, 2011 to December 31, 2015, and MIBOR rate has been taken as a substitute for risk-free interest rate for the same period from RBI website. The primary data which include the mathematical computation and theoretical justification for Black-Scholes Model option price.

\section{BSM Options Pricing Model}

$\mathrm{C}=\mathrm{S} * \mathrm{~N}(\mathrm{~d} 1)-\mathrm{K}^{*} \mathrm{e}^{\wedge}-\mathrm{rt} * \mathrm{~N}(\mathrm{~d} 2)$

$\mathrm{P}=\mathrm{K}^{*} \mathrm{e}^{\wedge}-\mathrm{rt} * \mathrm{~N}(-\mathrm{d} 2)-\mathrm{S} * \mathrm{~N}(-\mathrm{d} 1)$

$\mathrm{d} 1=\ln (\mathrm{S} / \mathrm{K})+\left(\mathrm{r}+\left(\mathrm{SD}^{\wedge} 2 / 2\right)\right) * \mathrm{t} / \mathrm{sd}^{*} \operatorname{sqrt}(\mathrm{t})$

$\mathrm{d} 2=\mathrm{d} 1-\operatorname{sd} * \operatorname{sqrt}(\mathrm{t})$

where,

$\mathrm{C}=$ Call price

$\mathrm{S}=$ Stock price

$\mathrm{K}=$ Strike price

$\mathrm{r}=$ Risk-free interest rate

$\mathrm{t}=$ Time to maturity

$\mathrm{N}=$ Normal distribution

$\mathrm{P}=$ Put price

\section{Paired Sample t test}

$\mathrm{N}$ : Total Numbers

$$
t=\sqrt{\frac{\sum D^{2}-\left(\frac{\left(\sum D\right)}{N}\right)}{(N-1)(N)}}
$$

$\Sigma \mathrm{D}$ : Sum of the differences

$\Sigma D^{2}$ : Sum of the squared differences

$(\Sigma D)^{2}$ : Sum of the differences squared.

\section{Hypothesis}

$\mathbf{H}_{\mathbf{0}}$ : There is no any significant difference between the theoretical or calculated price of option obtained through BSM model and the market price of the Nifty 50 Index.

Table No: 1 Trends in Equity Derivatives Segments of NSE

\begin{tabular}{|c|c|c|c|c|}
\hline \multirow{3}{*}{ Year } & \multicolumn{4}{|c|}{ Index Options } \\
\hline & \multicolumn{2}{|c|}{ Call } & \multicolumn{2}{|c|}{ Put } \\
\hline & $\begin{array}{l}\text { No. of } \\
\text { Contracts }\end{array}$ & $\begin{array}{l}\text { Turnover } \\
\text { (crore) }\end{array}$ & $\begin{array}{l}\text { No. of } \\
\text { Contracts }\end{array}$ & $\begin{array}{l}\text { Turnover } \\
\text { (crore) }\end{array}$ \\
\hline $\begin{array}{l}2011-1 \\
2\end{array}$ & $\begin{array}{c}42,80,34,67 \\
7\end{array}$ & $\begin{array}{c}1,15,54,30 \\
1\end{array}$ & $\begin{array}{c}43,59,83,05 \\
9\end{array}$ & $\begin{array}{c}1,11,65,73 \\
1\end{array}$ \\
\hline $\begin{array}{c}2012-1 \\
3\end{array}$ & $\begin{array}{c}40,85,30,47 \\
7\end{array}$ & $\begin{array}{c}1,15,81,48 \\
5\end{array}$ & $\begin{array}{c}41,23,46,67 \\
2\end{array}$ & $\begin{array}{c}1,12,00,08 \\
9\end{array}$ \\
\hline $\begin{array}{c}2013-1 \\
4\end{array}$ & $\begin{array}{c}45,20,47,06 \\
8\end{array}$ & $\begin{array}{c}1,38,23,05 \\
9\end{array}$ & $\begin{array}{c}47,65,18,10 \\
7\end{array}$ & $\begin{array}{c}1,39,44,28 \\
2\end{array}$ \\
\hline & $\begin{array}{l}\text { ished By: } \\
\text { Eyes Intellige } \\
\text { iences Publice }\end{array}$ & Engineeri & & \\
\hline
\end{tabular}




\begin{tabular}{|c|c|c|c|c|}
\hline $\begin{array}{c}2014-1 \\
5\end{array}$ & $70,14,16,67$ & $2,07,71,43$ & $67,72,26,19$ & $1,91,51,22$ \\
& 0 & 9 & 3 & 4 \\
\hline $\begin{array}{c}2015-1 \\
6\end{array}$ & $83,76,83,83$ & $2,60,63,79$ & $78,58,44,65$ & $2,28,88,14$ \\
& 0 & 1 & 6 & 0 \\
\hline
\end{tabular}

Source: NSE website

\section{RESULTS AND DISCUSSION}

Table No: 2 Paired sample t test for Nifty Index 50

\begin{tabular}{|c|c|c|c|c|c|c|c|c|c|}
\hline \multirow{3}{*}{ Year } & & \multicolumn{5}{|c|}{ Paired Differences t test } & \multirow{3}{*}{$t$} & \multirow{3}{*}{$d f$} & \multirow{3}{*}{$\begin{array}{c}\text { Sig, } \\
\text { (2-tailed) }\end{array}$} \\
\hline & & \multirow[t]{2}{*}{ Mean } & \multirow{2}{*}{$\begin{array}{c}\text { Std. } \\
\text { Deriation }\end{array}$} & \multirow{2}{*}{$\begin{array}{c}\text { Std. Error } \\
\text { Mean }\end{array}$} & \multicolumn{2}{|c|}{$\begin{array}{l}\text { 95\% Confidence Interval of } \\
\text { the Difference }\end{array}$} & & & \\
\hline & & & & & Lower & Upper & & & \\
\hline $\begin{array}{l}2011 \\
\text { Call }\end{array}$ & $\begin{array}{ll}\text { Theoretical } & \& \\
\text { Market Call Price }\end{array}$ & 18.66016 & 18.27451 & .40924 & 17.85757 & 19.46275 & 45.597 & 1993 & .000 \\
\hline $\begin{array}{l}2012 \\
\text { Call }\end{array}$ & $\begin{array}{lr}\text { Theoretical } & \& \\
\text { Market Call Price }\end{array}$ & 5.47831 & 10.85226 & .25129 & 4.98547 & 5.97116 & 21.800 & 1864 & .000 \\
\hline $\begin{array}{l}2013 \\
\text { Call }\end{array}$ & $\begin{array}{lr}\text { Theoretical } & \& \\
\text { Market Call Price }\end{array}$ & 18.68403 & 25.93193 & .59212 & 17.52276 & 19.84530 & 31.554 & 1917 & .000 \\
\hline $\begin{array}{l}2014 \\
\text { Call }\end{array}$ & $\begin{array}{l}\text { Theoretical \& } \\
\text { Market Call Price }\end{array}$ & 5.88656 & 29.67892 & .69993 & 4.51380 & 7.25932 & 8.410 & 1797 & .000 \\
\hline $\begin{array}{l}2015 \\
\text { Call }\end{array}$ & $\begin{array}{|lr|}\text { Theoretical } & \& \\
\text { Market Call Price }\end{array}$ & 22.19867 & 41.45024 & .95879 & 20.31826 & 24.07908 & 23.153 & 1868 & .000 \\
\hline $\begin{array}{l}\text { For All } \\
5 \text { Years } \\
\text { Call }\end{array}$ & $\begin{array}{l}\text { Theoretical \& } \\
\text { Market Call Price }\end{array}$ & 14.33023 & 28.05102 & .28865 & 13.76442 & 14.89605 & 49.646 & 9443 & .000 \\
\hline \begin{tabular}{l|}
2011 \\
Put
\end{tabular} & $\begin{array}{l}\text { Theoretical \& } \\
\text { Market Put Price }\end{array}$ & .95983 & 13.67839 & .30632 & .35909 & 1.56057 & 3.133 & 1993 & .002 \\
\hline $\begin{array}{l}2012 \\
\text { Put }\end{array}$ & $\begin{array}{l}\text { Theoretical \& } \\
\text { Market Put Price }\end{array}$ & .7 .98988 & 13.63602 & .31575 & .8 .60915 & $.7,37061$ & .25 .304 & 1864 & .000 \\
\hline $\begin{array}{l}2013 \\
\text { Put }\end{array}$ & $\begin{array}{l}\text { Theoretical \& } \\
\text { Market Put Price }\end{array}$ & 3.23972 & 19.14855 & .43723 & 2.38222 & 4.09722 & 7.410 & 1917 & .000 \\
\hline $\begin{array}{l}2014 \\
\text { Put }\end{array}$ & $\begin{array}{l}\text { Theoretical \& } \\
\text { Market Put Price }\end{array}$ & .8 .43723 & 30.61497 & .72200 & .9 .85328 & -7.02118 & .11 .686 & 1797 & .000 \\
\hline $\begin{array}{l}2015 \\
\text { Put }\end{array}$ & $\begin{array}{l}\text { Theoretical \& } \\
\text { Market Put Price }\end{array}$ & 280113 & 34.02827 & .78711 & 1.25742 & 4.34484 & 3.559 & 1868 & .000 \\
\hline $\begin{array}{l}\text { For All } \\
5 \text { Years } \\
\text { Put }\end{array}$ & $\begin{array}{l}\text { Theoretical \& } \\
\text { Market Put Price }\end{array}$ & -1.76919 & 24.18598 & .24888 & .2 .25705 & -1.28134 & .7 .109 & 9443 & .000 \\
\hline
\end{tabular}

\section{INTERPRETATION}

The above table has clearly explained that the $t$ value for both call and put price of all 5 years were less than 0.05 . Hence, the hypothesis of this study were accepted and proved that there is no any significant deviation between the calculated values of theoretical and market prices for both call and put in all the 5 years. This result indicates that the BSM model perfectly fits in this period.

\section{LIMITATIONS OF THE STUDY}

The study was limited to only Nifty 50 index Option in National Stock Exchange and never considered the Bombay Stock Exchange due to the low traded volume from January 1, 2011 to December 31, 2015. The study has taken BSM model price only to study the options price theorem and not consider other pricing models like Binomial tree model, Jump valuation model etc.

\section{VII.CONCLUSION}

The Black Sholes options pricing model is one of the standardized pricing models for options contract in India, which only deals with the European option's price. This paper has offered a clarified detail about the efficiency of BSM model in the options market for the research period $2011-2015$. The $t$ test was applied and got the result as there is no any significant association between the market price and the theoretical calculated price which we got through the BSM model. This study has examines the efficiency of S\&P CNX Nifty 50 index options using the Black- Scholes Model and the dynamic hedging strategy. The Black-Scholes Model identifies that there is no any other significant different of market prices from theoretical option prices which obtained through the Black-Scholes Model which proves this model was more appropriate and helped the investors to calculate the option price.

\section{REFERENCES}

[1]. (https://corporatefinanceinstitute.com/resources/knowledge/valuation/op tion-pricing-models/)

[2]. Kaushik Amin, Joshua D. Coval and H. Nejat Seyhun (2004), Index Option Prices and Stock Market Momentum, The Journal of Business , Vol. 77, No. 4, October pp. 835-874 Published by: The University of Chicago Press

[3]. https://theoptionprophet.com/blog/7-factors-that-affect-an-option-s-price

[4]. Jelena Paunović, Singidunum (2014), Options, Greeks, and Risk Management, Journal of Applied Science, SJAS 2014, 11 (1): 74-83 ISSN 2217-8090.

[5]. Debaditya Mohanti P. K. Priyan (2013), Ex-ante Test of Lower Boundary Condition and Market Efficiency: Evidence from Indian Index Options Market, Management Review Volume XXIII April - May 2013, ISSN: 0971-1023 NMIMS

[6]. Lucy F. Ackert, Yisong S. Tian (2001), Efficiency in Index Options Markets and Trading in Stock Baskets, Journal of Banking \& Finance 2001, 1607-1634

[7]. Joshua Krausz (1985) Option parameter analysis and market efficiency tests: a simultaneous solution approach, Applied Economics, 17:5, 885-896

[8]. Alok Dixit Surendra S. Yadav and P.K. Jain, (2010), Informational efficiency of implied volatilities of S\&P CNX Nifty index options", Journal of Advances in Management Research, Vol. 7 Iss 1 pp. 32 - 57

[9]. Debaditya Mohanti P. K. Priyan (2014), An Empirical Test of Market Efficiency of Indian Index Options Market Using the Black-Scholes Model and Dynamic Hedging Strategy Paradign 18(2) 221-237, SAGE publications.

[10]. http://www.mkaranasos.com/FEBlackScholes.pdf 